\title{
Ewelina Sobotko
}

Uniwersytet Warmińsko-Mazurski

Wydział Nauk Ekonomicznych

Katedra Analizy Rynku i Marketingu

msobotko@gmail.com

\section{Style życia we współczesnym społeczeństwie i ich wpływ na zachowanie rynkowe młodych konsumentów}

\author{
Artykuł nadesłany: 22 czerwca 2017 r.; artykuł zaakceptowany: 15 grudnia 2017 r. \\ JEL Classification: D11, E21, Q01, Q56
}

Keywords: lifestyle, consumer behaviour, consumerism, sustainable development

\begin{abstract}
Lifestyles in modern society and their impact on the market behaviour of the young consumers

In modern society one of the basic goals of human life is to continually make and spend money. Young consumers, as people brought up under the conditions of this process formed their own market behavior and determined a certain lifestyle. In this article, the author presents the relationship between the current life styles in contemporary society and the behaviour of young people in the market. Observation of the behaviour of the older generation by the representatives of the $Y$ generation and the changes taking place on the market as a result of globalization have resulted in the formation of two different directions in the patterns of the consumption of young people. It can be observed that there are selfish consumers on the one hand and altruistic consumers on the other hand, who behave according to assumptions of sustainable consumption. This study focuses on the presentation of the second type of young consumers. They were indicated for their subgroups and assigned to appropriate consumer trends and to the lifestyle related to their behaviour.
\end{abstract}

\section{Wstęp}

W dobie przemian globalizacyjnych i konsumpcjonizmu młode społeczeństwo rozpoczęło poszukiwanie nowych wzorców i postaw konsumenckich, które będą 
świadome i odpowiedzialne. Dostrzegają zjawiska wpływające niekorzystnie zarówno na sfery społeczne, ekonomiczne, jak i przyrodnicze. Idea zrównoważonego rozwoju nakłania do analizy specyficznych zachowań nabywczych. Istnieją różne czynniki warunkujące zachowania konsumenckie. Do najważniejszych zalicza się preferowany przez nich styl życia, który w licznych przypadkach jest podstawowym motywem zakupu i źródłem rozmaitych działań rynkowych konsumentów. Kluczowymi cechami, które charakteryzują styl życia współczesnego społeczeństwa, są mobilność, aktywny model spędzania czasu wolnego oraz korzystanie z technologii teleinformacyjnej.

Niniejsze opracowanie odnosi się do zachowań młodych konsumentów, czyli grupy nabywców charakteryzujących się silnymi relacjami społecznymi, co czyni ich bardziej świadomymi i otwartymi w stosunku do nowych trendów. Biorąc pod uwagę koncepcję zrównoważonego rozwoju, należy wskazać na ewolucję postępowania młodego konsumenta na rynku — od konsumenta egoistycznego do konsumenta moralnie odpowiedzialnego. Przekształcenia w zachowaniach nabywczych kierują do tworzenia nowych trendów w konsumpcji. Zainteresowani zachowaniami młodych konsumentów są nie tylko przedstawiciele różnorodnych dziedzin naukowych, lecz także praktycy biznesowi. Wiedza płynąca z tego zagadnienia stanowi główny fundament do określenia strategii marketingowych przedsiębiorstw. W artykule podjęto próbę wskazania roli stylu życia w kształtowaniu zachowań rynkowych młodych konsumentów oraz wskazania typologii młodych nabywców reprezentujących różne style życia. Szczególną uwagę zwrócono na te trendy w zachowaniach rynkowych nabywców należących do pokolenia Y, które są zbieżne z ideą zrównoważonego rozwoju. Najpopularniejszymi są: etnocentryzm konsumencki, dematerializacja, konsumpcja współpracująca, freeganizm, domocentryzm i dekonsumpcja. Ze względu na teoretyczny charakter opracowania wykorzystano w nim wyłącznie wtórne źródła informacji.

\section{Styl życia - aspekt teoretyczny}

Jednym z podstawowych czynników determinujących zachowanie konsumenta jest styl życia. Funkcjonuje on jako pojęcie, które jest często zestawiane, a nawet zastępowane takimi określeniami, jak sposób, jakość i poziom życia, wzory zachowań, wartości, a także postawy. W wielu publikacjach naukowych można doszukać się różnych prób sformułowania tego terminu, gdyż jest on przedmiotem zainteresowania badaczy obszarów ekonomicznych, psychologicznych, socjologicznych, pedagogicznych i medycznych. Powoduje to, że nie istnieje jedno, akceptowane przez wszystkich objaśnienie, czym jest styl życia. Warunkiem odniesienia się do właściwej definicji tego zagadnienia jest szczegółowa analiza literatury przedmiotu (Sowa 2014, s. 126; Rudnicki 2009, s. 12). Propozycje określenia stylu życia przez wybranych naukowców przedstawiono w tabeli 1. 
Tabela 1. Wybrane ujęcia terminu „styl życia” według różnych autorów

\begin{tabular}{|c|c|c|c|}
\hline & Autor & Rok & Definicja \\
\hline 1. & Andrzej Tyszka & 1974 & $\begin{array}{l}\text { „styl życia jest to kulturowo uwarunkowany stopień i sposób za- } \\
\text { spokajania potrzeb i realizowania aspiracji za pomocą możliwości } \\
\text { i prerogatyw wynikających z zajmowanej pozycji społecznej” }\end{array}$ \\
\hline 2. & $\begin{array}{l}\text { Aldona } \\
\text { Jawłowska }\end{array}$ & 1975 & $\begin{array}{l}\text { „styl życia jest }[\ldots] \text { formą narzuconą na całokształt pozornie cha- } \\
\text { otycznych i krzyżujących się ciągów czynności }[\ldots] \text {, jest struktu- } \\
\text { ralizacją procesów ludzkiej aktywności wedle przyjętych założeń } \\
\text { światopoglądowych, hierarchii celów i reguł, ich realizacji, które } \\
\text { stanowią główną oś strukturalizacji” }\end{array}$ \\
\hline 3. & $\begin{array}{l}\text { Andrzej } \\
\text { Siciński }\end{array}$ & 1977 & $\begin{array}{l}\text { „[styl życia to - E.S.] zespół codziennych zachowań charaktery- } \\
\text { stycznych dla danej zbiorowości lub jednostki” }\end{array}$ \\
\hline 4. & $\begin{array}{l}\text { Elżbieta } \\
\text { Duliniec }\end{array}$ & 1986 & $\begin{array}{l}\text { „styl życia to wzory konsumpcji uzależnione od preferowanych } \\
\text { przez klasę społeczną lub grupę konsumentów form spędzania } \\
\text { czasu i wydawania pieniędzy. W znaczeniu ekonomicznym do- } \\
\text { tyczy sposobów wydawania pieniędzy oraz rodzaju nabywanych } \\
\text { dóbr i usług” }\end{array}$ \\
\hline 5. & $\begin{array}{l}\text { Gordon } \\
\text { R. Foxall } \\
\text { i Ronald } \\
\text { E. Goldsmith }\end{array}$ & 1998 & $\begin{array}{l}\text { „[styl życia to - E.S.] uznany przez grupę lub jednostkę wybiera- } \\
\text { ny sposób zaspokajania potrzeb” }\end{array}$ \\
\hline 6. & Barbara Fatyga & 1999 & $\begin{array}{l}\text { „[styl życia to - E.S.] kulturowo uwarunkowany sposób realizacji } \\
\text { potrzeb, nawyków i norm; regulują go układy wartości przyjęte } \\
\text { przez jednostki i grupy. Te układy wartości stanowią tzw. zasady } \\
\text { stylów życia, umożliwiając ich realizatorom odczuwanie swojego } \\
\text { życia jako względnie spójnego i sensownego" }\end{array}$ \\
\hline 7. & $\begin{array}{l}\text { Michael } \\
\text { R. Solomon }\end{array}$ & 2006 & $\begin{array}{l}\text { 1. „styl życia to nie tylko to, ile i jak wydaje się, ale to deklaracja, } \\
\text { kim jesteśmy, a kim nie jesteśmy. Wyraża się to przez zachowania } \\
\text { symboliczne i posługiwanie się dobrami-symbolami”; } \\
\text { 2. „styl życia to wzorzec konsumpcji odzwierciedlający to, co } \\
\text { dana osoba lubi robić i na co wydaje pieniądze. Pojęcie to oznacza } \\
\text { sposób rozporządzania swoimi dochodami przez konsumentów, } \\
\text { zarówno w odniesieniu do ogólnego przeznaczania pieniędzy na } \\
\text { różne produkty i usługi, jak i bardziej szczegółowych decyzji do- } \\
\text { tyczących wydawania ich na określone produkty w ramach okre- } \\
\text { ślonej kategorii” }\end{array}$ \\
\hline
\end{tabular}

Źródło: Tyszka 1974, s. 105; Fatyga 1999, s. 9; Solomon 2006, s. 216; Duliniec 1986, s. 303; Foxall, Goldsmith 1998, s. 200; Jawłowska 1975, s. 224.

Styl życia ma wiele wymiarów, w których można zaobserwować poziom konkretny, czyli zachowania i działania. Na ich podstawie można wnioskować o pozostałych. Poziom, który w sposób ogólny wpływa na zachowania, jest reprezentowany przez wartości i normy, które warunkują zainteresowania człowieka. Kształtują także jego poglądy i przekonania, co bezpośrednio wpływa na działania jednostki (Sowa 2016, s. 138). Proces ten wraz ze składowymi stylu życia zobrazowano na rysunku 1. 


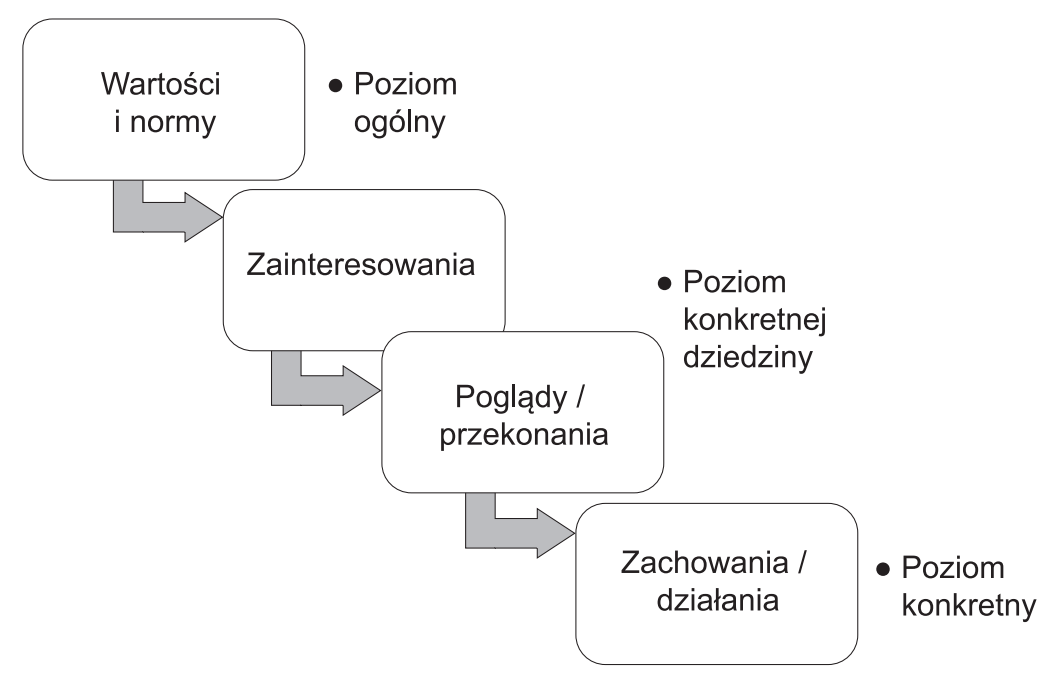

Rysunek 1. Elementy stylu życia

Źródło: Antonides, Van Raaij 2003, s. 85.

Oznacza to, że stylem życia można nazwać zarówno obserwowalne zachowania w życiu codziennym, jak i nieobserwowalne wartości, które człowiek wyraża przy pomocy określonych zachowań. Jest on również uznawany za podstawowe źródło działań, które konsumenci reprezentują na rynku (Rudnicki 2009, s. 12). Należy jednak pamiętać, że styl życia, pomimo że stanowi własny wybór, jest uznawany za fenomen grupowy, a osobisty styl życia nie jest indywidualnym wzorcem zachowania, gdyż jest on następstwem współudziału w różnorodnych kręgach społecznych (Feldman, Thielbar 1975, s. 2-4). W ten sposób tworzy się zbiorowy styl życia, który upodabnia ludzi do siebie. Tworzenie się grup o charakterystycznych zachowaniach i działaniach, takich jak na przykład spędzanie czasu wolnego czy nawyki zakupowe, pozwala na ich identyfikację (Sowa 2016, s. 137).

\section{Style życia we współczesnym społeczeństwie}

Znajomość typologii stylów życia jest przydatna w formowaniu segmentacji rynkowej. Dane psychograficzne wykorzystywane w praktyce biznesowej ułatwiają przygotowanie strategii marketingowych, tworzenie narzędzi komunikacji z konsumentem itp. Przykładem takiego działania jest program VALS (Values and Lifestyles), który został zaprojektowany przez Stanford Research Institute International. Wyróżniono w nim osiem korelatywnych stylów życia, które zostały podzielone na podstawie orientacji jednostki, a także jej poziomu zasobów. Orientacja własna jednostki klasyfikowała określone wzory postaw i zachowań ludzkich, które reprezentowały to, w jaki sposób człowiek chce być postrzegany 
przez resztę społeczeństwa. Kryterium zasobowe dotyczyło wielkości dochodu jednostki, jej wykształcenia, inteligencji, zarządzania własnym zdrowiem oraz skłonności do konsumpcji dóbr i usług (Rudnicki 2009, s. 13-14). Podział stylów życia konsumentów we współczesnym społeczeństwie w oparciu o te założenia przedstawiono na rysunku 2 .

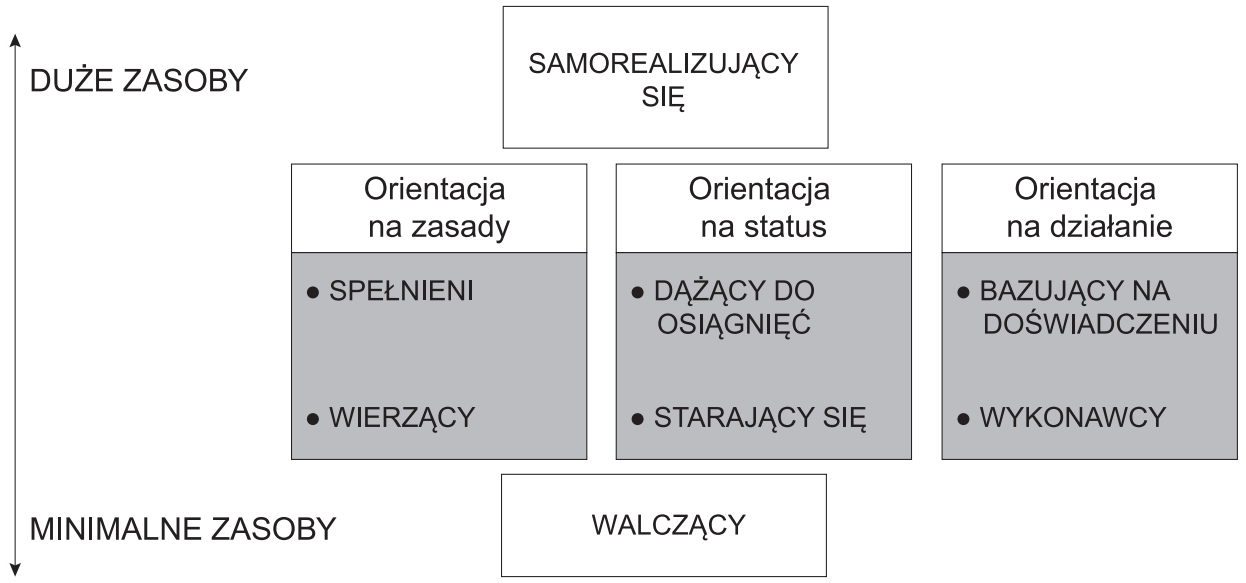

Rysunek 2. Style życia we współczesnym społeczeństwie

Źródło: Rudnicki 2009, s. 14.

Wszystkie segmenty odnoszą się do ludzi o specyficznych cechach, co więcej, każdy z nich charakteryzuje się odmiennym zachowaniem na rynku (Rudnicki 2009, s. 14-15):

1. samorealizujący się — typ osób, które są przyciągane przez produkty luksusowe; są nastawieni na sukces i zazwyczaj pełnią poważne obowiązki w miejscu pracy; mają wysokie poczucie własnej wartości, a ich zasoby są najwyższe ze wszystkich grup; chcą być niezależni i aktywni oraz ponadprzeciętnie dbają o wizerunek;

2. spełnieni - grupa wysoko rozwiniętych osób zmotywowanych ideałami; są odpowiedzialni i dobrze wykształceni, są świadomi ogólnej sytuacji światowej i wykazują otwarcie na nowe pomysły i zmiany społeczne; mają wysokie dochody, ale konsumują w sposób racjonalny;

3. wierzący - konserwatywni i przewidywalnymi konsumenci, którzy preferują znane marki, niechętnie zmieniają nawyki; ich życie skupia się na rodzinie, wspólnotach kościelnych czy narodowych; mają niewielkie dochody;

4. dążący do osiągnięć - zmotywowani sukcesem, zorientowani na pracę; są politycznie konserwatywni, respektują autorytet i status quo; preferują produkty najwyższej jakości; są skłonni obnosić się ze swoim sukcesem i dobrami;

5. starający się — grupa osób o niskim poziomie zasobów, które są motywowane osiągnięciami; mają wartości bardzo zbliżone do „dążących do osiągnięćc, jed- 
nak posiadają mniejsze zasoby gospodarcze, społeczne i psychologiczne; styl jest dla nich niezwykle ważny, ponieważ dążą do naśladowania ludzi podziwianych;

6. bazujący na doświadczeniu — charakteryzują się energicznością, uprawiają dużo sportu i są aktywni społecznie; konsumują pod wpływem impulsu, wydają pieniądze na życie towarzyskie, interesują się modą, muzyką i nowymi produktami, usługami, często odwiedzają restauracje typu fast-food; jest to grupa, do której należą osoby najmłodsze (relatywnie do pozostałych segmentów);

7. wykonawcy — obojętni na luksus, są praktycznymi ludźmi, którzy cenią samowystarczalność; skupieni na rodzinie i pracy, mało zainteresowani tym, co się dzieje na świecie; jako konsumenci doceniają praktyczne i funkcjonalne produkty;

8. walczący - są konsumentami o najniższych dochodach; mają zbyt mało zasobów, aby można było je uwzględnić w jakiejkolwiek innej orientacji konsumentów; są najstarsi spośród wszystkich segmentów; zazwyczaj wybierają te same marki, korzystają z kuponów i poszukują przecen; mają duże zaufanie do reklamy.

\section{Konsumpcja zrównoważona jako alternatywa dla konsumpcjonizmu}

Najłatwiejszą drogą dla społeczeństwa jest uległość wobec konsumpcyjnego stylu życia, który nazywany jest chorobą cywilizacyjną współczesnego społeczeństwa. Łączy się on z doktryną hedonizmu materialistycznego, w której przyjemność jest dla człowieka najważniejszym dobrem i celem życiowym (Kozłowski, Rutkowska 2016, s. 237). W konsumpcjonizmie konsumpcja staje się pewnego rodzaju statusem społecznym i stylem życia, a konsument — egoistą, który nie jest zainteresowany dobrem wspólnym ani przyszłością ludzkości (Drapińska 2015, s. 277). Według raportu World Wide Fund for Nature do 2030 roku ludzkości na całym świecie będą potrzebne bogactwa naturalne nie mniejsze niż z dodatkowej planety, aby zaspokoić jej potrzeby. Takie sygnały podkreślają istotność problemu o zagrożeniu środowiskowym na poziomie globalnym, co dalej wskazuje na konieczność zmiany struktury konsumpcji, a także jej poszczególnych modeli (Wasilik 2014, s. 68).

Konsumpcja jest charakterystyczna dla jednostki, natomiast konsumpcjonizm to cecha zbiorowości. Postawom hedonistycznym i konsumpcjonizmowi może się przeciwstawić wspólnota obywatelska konsumująca w sposób zrównoważony. Zrównoważona konsumpcja jest zasadniczą częścią zrównoważonego rozwoju, którego celem jest poprawa jakości życia przy jednoczesnym utrzymaniu bogactwa zasobów naturalnych oraz równości społecznej (Kozłowski, Rutkowska 2016, s. 239). Początkowo konsumpcję zrównoważoną postrzegano jako dokonywanie takich wyborów przez konsumenta, które przybliżają urzeczywistnienie założeń zrównoważonego rozwoju. Konsumpcja zrównoważona przejawia się nie tylko 
w konsumowaniu dóbr ekologicznych, lecz także w oszczędnym i racjonalnym wykorzystaniu dóbr konsumpcyjnych i zasobów naturalnych. Istotne jest również ilościowe ograniczenie spożycia wyrobów (Kryk 2013, s. 8).

Postawy antykonsumpcyjne mogą wynikać z wielu czynników. Mając na uwadze motywy ludzi do ograniczania konsumpcji oraz liczbę produktów, które konsumenci przestają nabywać, wyodrębniono warianty zrównoważonej konsumpcji (zob. rysunek 3).

Wszystkie produkty

Liczba produktów

Wszystkie produkty lub marki

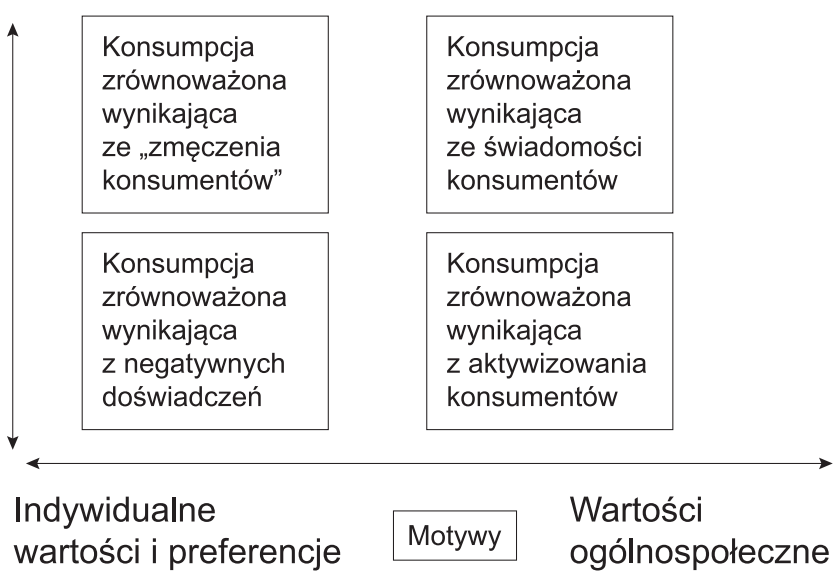

Rysunek 3. Podział zrównoważonej konsumpcji ze względu na motywy i zakres

Źródło: Kryk 2013, s. 9.

Konsumpcja zrównoważona, która jest następstwem „zmęczenia konsumentów", odnosi się do wszystkich produktów i jest powiązana z natłokiem informacji, ciągłością wypuszczania coraz większej liczby nowych produktów i szybkim tempem na rynku. Osoby, które rezygnują ze spożycia w tym kontekście, zazwyczaj kierują się indywidualnymi wartościami oraz samorealizacją i nie zależy im na posiadaniu. Oznacza to, że umyślnie odstępują od konsumpcji tego, co nie jest uznawane przez nich za konieczne. Konsumpcja zrównoważona powstała w wyniku negatywnych doświadczeń obejmuje konkretne dobra, które mogą być odrzucane ze względu na typ lub markę. Motywem takiego działania jest negatywne zdanie o produkcie, ukształtowane jako efekt wcześniejszych doświadczeń niekorzystnych dla konsumenta. Konsumpcja zrównoważona jest rezultatem aktywizowania konsumentów w sytuacji, gdy wynika z wykluczenia ze spożycia tych dóbr, które są niezgodne ze stanowiskami reprezentowanymi przez określone grupy społeczne bądź polityczne (Zarałek 2014, s. 196-197). Według Barbary Kryk (2013, s. 10) najbardziej oczekiwaną odmianą konsumpcji zrównoważonej jest będąca konsekwencją świadomości ludzi w obszarze odpowiedzialności społecznej i środowiskowej. Konsumenci racjonalizują swoje spożycie dóbr i usług, co jest związane z hierarchią ich wartości i ideologią zgodną z koncepcją zrównoważonego rozwoju. 
Należy zaakcentować także rolę środowiska naturalnego w przemianie modelu konsumpcji. Realny poziom zagrożenia dla ludzi, wywołany zanieczyszczeniami, powoduje, że rośnie ryzyko pojawiania się różnego rodzaju chorób, w tym tych śmiertelnych. Konsumpcja zrównoważona może być zatem wywołana też obawą o stan zdrowia jednostki i jej bliskich (Neale 2015, s. 142).

\section{Charakterystyka podmiotu rozważań}

Dokonując analizy różnych stanowisk prezentowanych w wielu publikacjach naukowych, napotkano trudność we właściwym określeniu podmiotu rozważań, gdyż nie było możliwe odszukanie jednoznacznego ujęcia, kim jest „młody konsument”. Według art. 15 Kodeksu cywilnego podmiotem na rynku są osoby, które ukończyły 13. rok życia. Odnosząc się do demografii, młodych konsumentów klasyfikuje się w przedziale wiekowym 16-25 lat (Chmielowska et al. 1972, s. 9). Według Anny Olejniczuk-Merty (2007, s. 7) nazywa się tak młodzież i dzieci od 7 do 19 lat, natomiast Izabela Sowa (2002, s. 175) zalicza do tej kategorii ludzi w wieku 23-38 lat, a Halina Szulce (2009, s. 637) wyróżnia przedział 15-29 lat. Z kolei Krzysztof Andruszkiewicz (2016, s. 113) uważa, że do rodzaju konsumenta młodego należą jednostki od kilkunastu do około 30 lat. Na potrzeby artykułu przyjęto, że młodymi konsumentami są osoby należące do pokolenia Y, urodzone pomiędzy 1982 a 2000 rokiem (Rich 2008, s. 73), ponieważ charakteryzują się wieloma wspólnymi cechami, które były w stanie już się ukształtować (Mróz 2013, s. 78).

Młody konsument jest istotnym elementem w społeczeństwie, a także w segmentacji rynkowej. Stanowi jej osobny fragment, ponieważ jego zachowania są odmienne niż pozostałych grup. W inny sposób postrzega świat, odbiera komunikaty z otoczenia, ma odmienne potrzeby i systemy wartości. Działalność tej grupy na rynku jest utrudniona poprzez liczne bariery: wiek, uwarunkowania legislacyjne, wysokość dochodu, dostęp do informacji, poziom edukacji czy rozumienie działania systemu rynkowego (Adamczyk 2014, s. 7).

Pokolenie Y jest istotną siłą nabywczą i decyzyjną, ponieważ zarządza systematycznie powiększającymi się środkami pieniężnymi. Nie tylko osoby mieszkające same mają główny wpływ na decyzje nabywcze, lecz także młodzież pozostająca przy rodzicach jest $\mathrm{w}$ stanie intensywnie oddziaływać na rodzinę w kwestii zakupowej. Obierane przez nich stanowiska mogą być różne (Adamczyk 2014, s. 7):

- bierni uczestnicy,

- inicjatorzy,

— informatorzy i doradcy,

- decydenci. 
Młodzi ludzie, którzy obierają konkretny styl życia, jednocześnie ogłaszają swoją przynależność do danej grupy społecznej lub uwydatniają swój indywidualizm. Styl życia młodych konsumentów jest swojego rodzaju miarą, za pomocą której oceniane są zachowania jednostki i innych, a także dokonywane są porównania pomiędzy nimi (Dubis 2013, s. 43).

\section{Młodzi konsumenci a konsumpcjonizm}

Odwołując się do konsumentów „bazujących na doświadczeniu”, których średnia wieku wynosiła 25 lat w typologii stylów życia VALS, należy zwrócić uwagę, że z jednej strony wykazywali zainteresowanie działalnością na rzecz społeczeństwa, a z drugiej oddawali się konsumpcjonizmowi. Sama nazwa tej kategorii wskazuje na to, że ta grupa młodych ludzi ukształtowała się w wyniku obserwacji współczesnego społeczeństwa, a ono nie konsumuje w sposób zrównoważony¹. Wojciech Kozłowski i Anna Rutkowska (2016, s. 243) zwracają natomiast uwage na „zmianę paradygmatu funkcjonowania konsumenta na rynku”. Jest to przeobrażenie zachowań konsumentów, którzy są coraz bardziej świadomi swojego otoczenia, zarówno społecznego, jak i naturalnego. Konsument moralnie hedonistyczny (egoistyczny) zmienia się w konsumenta moralnie odpowiedzialnego (prospołecznego, „obywatela”). Współczesne egoistyczne działania społeczeństwa skłoniły konsumentów do poszukiwania stylu życia alternatywnego do konsumpcjonistycznego. Iwona Escher i Joanna Petrykowska (2015, s. 129) uważają, że młodzi konsumenci są lepiej wykształceni w poszanowaniu środowiska naturalnego i mają większą świadomość ekologiczną, a także zachowują się w sposób proekologiczny. Inne stanowisko przedstawia Grażyna Adamczyk (2014, s. 13), który opisuje młodego konsumenta jako hedonistę, czerpiącego satysfakcję, przyjemność i radość z nabywania i posiadania, traktując konsumpcję jako ważny element stylu życia. Z kolei B. Kryk w wynikach badań prezentuje:

[c]iekawe jest to - a właściwie można to było przewidzieć, obserwując zachowania społeczne że nieoszczędzanie energii jest największe wśród osób młodych w wieku 20-29 lat oraz uczniów i studentów, którzy powinni być uświadomieni ekologicznie. (Kryk 2013, s. 15)

Oznacza to, że można zauważyć dwa główne kierunki dzielące zachowania młodych konsumentów, wyróżniając egoistów i altruistów (zob. tabela 2).

${ }^{1}$ Badania wykonane na próbie 200 mieszkańców Warszawy w 2008 roku przez Bogdana Mroza, obejmujące codzienne zachowania zakupowe Polaków, dowiodły, że nie postępują oni zgodnie z zasadami zrównoważonej konsumpcji, a ich postępowanie różni się od społecznie pożądanych wzorców, będąc zbliżone do postaw hedonistycznych (Mróz 2009, s. 25-28). 
Tabela 2. Dwa główne kierunki odpowiedzi młodych konsumentów na style życia prowadzone przez społeczeństwo

\begin{tabular}{l|l|l}
\hline $\begin{array}{c}\text { Nazwa młodego } \\
\text { konsumenta }\end{array}$ & \multicolumn{1}{c}{ Wartości } & \multicolumn{1}{c}{ Zachowania } \\
\hline $\begin{array}{l}\text { egoista, } \\
\text { hedonista }\end{array}$ & $\begin{array}{l}\text { rozrywka, samorealizacja, } \\
\text { indywidualizm, egocentryzm }\end{array}$ & $\begin{array}{l}\text { - chęć wyróżnienia siebie poprzez } \\
\text { konsumpcję, } \\
\text { - intensywna konsumpcja, } \\
\text { - silna reakcja na działania marketingowe }\end{array}$ \\
\hline $\begin{array}{l}\text { altruista, } \\
\text { społecznie } \\
\text { odpowiedzialny }\end{array}$ & $\begin{array}{l}\text { oszczędność, gospodarność, } \\
\text { odpowiedzialność }\end{array}$ & $\begin{array}{l}\text { - wolontariat, } \\
\text { - udział w akcjach społecznych, } \\
\text { - udzielanie pomocy potrzebującym }\end{array}$ \\
\hline
\end{tabular}

Źródło: opracowanie własne na podstawie: Mazurek-Łopacińska 2011, s. 49.

Egoiści są grupą oddającą się konsumpcjonizmowi. Są podatni na modę, działania marketingowe, a także odczuwają głęboką presję wywoływaną przez masowe media i trendy w kulturze popularnej. Prowadzą indywidualne i ekspresyjne życie. Z kolei odpowiedzialni społecznie charakteryzują się zaangażowaniem w pomoc innym, są wrażliwi na problemy niepełnosprawnych. Wykazują się zainteresowaniem kwestią ochrony środowiska naturalnego, pokoju i bezpieczeństwa na poziomie lokalnym, krajowym i globalnym. Są bardzo zintegrowani z otoczeniem, a aktywność społeczna przynosi im satysfakcję (Mazurek-Łopacińska 2011, s. 50).

\section{Typy młodych konsumentów w kontekście idei zrównoważonego rozwoju}

Przedsiębiorcy powinni systematycznie badać rynek i korzystać z szans, jakie przynoszą im zmiany w jego otoczeniu. Obserwacja rynku, stylów życia, mody i obyczajów powoduje możliwość określenia trendów konsumenckich, które przyczyniają się do opracowania odpowiednich dla tych segmentów, nowych strategii marketingowych (Andruszkiewicz 2016, s. 115).

Tabela 3. Typy zachowań młodych ludzi w obszarze konsumpcji zrównoważonej

\begin{tabular}{c|c|c}
\hline \multicolumn{1}{c|}{ Konsument } & \multicolumn{1}{|c}{ Trend } & \multicolumn{1}{c}{ Wybrane elementy w stylu życia } \\
\hline „domownik" & domocentryzm & $\begin{array}{l}\text { - wolny czas spędza w domu, } \\
\text { - sam przygotowuje posiłki w domu i tam je spożywa, } \\
\text { a często najbardziej ceni ognisko domowe i rodzinę, } \\
\text { a nawet wykonuje pracę zawodową w domu }\end{array}$ \\
\hline
\end{tabular}

Ekonomia — Wroclaw Economic Review 23/4 (2017)

(C) for this edition by CNS 


\begin{tabular}{|c|c|c|}
\hline Konsument & Trend & Wybrane elementy w stylu życia \\
\hline $\begin{array}{l}\text { „Świadomy } \\
\text { i odpowiedzialny” }\end{array}$ & $\begin{array}{l}\text { świadoma } \\
\text { konsumpcja }\end{array}$ & $\begin{array}{l}\text { — zainteresowany zdrowiem, środowiskiem naturalnym, } \\
\text { sprawiedliwością społeczną i rozwojem osobistym, } \\
\text { — dzieli się tym, co ma, } \\
\text { — sortuje odpady, co umożliwia ich ponowne wykorzy- } \\
\text { stanie i w ten sposób chroni środowisko przed nadmierną } \\
\text { eksploatacją i zaśmieceniem, } \\
\text { — oszczędnie zużywa wodę i energię, } \\
\text { — ogranicza korzystanie ze środków chemicznych, } \\
\text { — stara się ograniczać konsumpcję do racjonalnych roz- } \\
\text { miarów, } \\
\text { — interesuje go, czy wybrane przez niego produkty po- } \\
\text { chodzą od społecznie odpowiedzialnego producenta }\end{array}$ \\
\hline „wolny” & freeganizm & $\begin{array}{l}\text { - bardzo ogranicza zakup dóbr i usług, } \\
\text { - poszukuje żywności i odzieży w śmietnikach, } \\
\text { - prosi o nadmiarowe i niepotrzebne produkty, zanim zo- } \\
\text { staną wyrzucone przez sprzedawców sklepów i restauracji, } \\
\text { - naprawia coś, co się zepsuło, zamiast wyrzucać, } \\
\text { - wymienia zbędne rzeczy z innymi i dzieli się z potrze- } \\
\text { bującymi, } \\
\text { - w świadomy sposób rezygnuje z nadmiernego kon- } \\
\text { sumpcjonizmu }\end{array}$ \\
\hline „kolaborant” & $\begin{array}{l}\text { konsumpcja } \\
\text { współpracująca }\end{array}$ & $\begin{array}{l}\text { — wymienia się rzeczami z innymi ludźmi, pożycza (rów- } \\
\text { nież odpłatnie) i dzieli się nimi, } \\
\text { — nie skupia się na posiadaniu, większą wagę przywiązu- } \\
\text { je do funkcji, przeżyć lub doświadczeń związanych z kon- } \\
\text { kretnym produktem, a następnie przekazuje go dalej, } \\
\text { — ogranicza konsumpcję indywidualną i niepotrzebne za- } \\
\text { kupy, } \\
\text { — integruje się i tworzy więzi społeczne }\end{array}$ \\
\hline „uduchowiony” & dematerializacja & $\begin{array}{l}\text { - ceni najbardziej dobra niematerialne, jak informacja, } \\
\text { wiedza, przeżycia estetyczne czy poprawa zdrowia, } \\
\text { - wyznaje filozofię „być, nie mieć”, } \\
\text { — jest ukierunkowany na przeżycia duchowe }\end{array}$ \\
\hline „racjonalny” & dekonsumpcja & $\begin{array}{l}\text { - preferuje bardziej jakość niż ilość, } \\
\text { — dąży do zaspokajania potrzeb niematerialnych, } \\
\text { — staje się świadomy konsekwencji swoich decyzji, pa- } \\
\text { trzy w przyszłość, } \\
\text { - ogranicza, unika produkowania odpadów poprzez ogra- } \\
\text { niczanie konsumpcji i sprowadza ją do rozmiarów racjo- } \\
\text { nalnych, } \\
\text { - wybiera produkty trwałe albo przetwarza zużyte }\end{array}$ \\
\hline „patriota” & etnocentryzm & $\begin{array}{l}\text { - ceni swój region i wspiera rozwój lokalnych inicjatyw, } \\
\text { — nie akceptuje globalnych wpływów ekonomicznych } \\
\text { i społecznych, } \\
\text { — jest świadomy narodowo, } \\
\text { — ważna jest dla niego także tradycja }\end{array}$ \\
\hline
\end{tabular}

Źródło: opracowanie własne na podstawie: Włodarczyk 2015, s. 242; Szul 2012, s. 318; Wasilik 2014, s. 71; Kryk 2011, s. 214; Kryk 2013, s. 7; Zalega 2013, s. 8; Mazurek-Łopacińska, Sobocińska 2009, s. 106; Wilczak 2016, s. 389.

Ekonomia — Wroclaw Economic Review 23/4 (2017)

(C) for this edition by CNS 
W tabeli 3 przedstawiono trendy w zachowaniach młodych ludzi konsumujących w sposób zrównoważony wraz z odpowiednimi dla nich stylami życia, które różnią się od siebie. Dzięki temu można wyodrębnić rozmaite potrzeby młodzieży i młodych dorosłych. Występowanie trendów w sferze konsumpcji podkreśla to, że coraz bardziej popularna staje się konsumpcja zrównoważona.

Poza wyznaczaniem trendów zachowań rynkowych zbiorowość pokolenia $\mathrm{Y}$ nieraz pełni rolę edukującą i daje przykład starszej generacji, jak użytkować dane dobra i usługi. Wywiera także wpływ na obszar biznesowy, korzystając z rozmaitych narzędzi, na przykład inicjatyw o charakterze bojkotowym, które pozwalają im na utrzymywanie równowagi w sferze konsumpcji (Mruk 2011, s. 22).

\section{Wnioski}

Młody konsument żyjący w konsumpcyjnym społeczeństwie znajduje się w bardzo trudnym położeniu, gdyż musi dużo wysiłku włożyć w to, żeby wybrać kierunek prowadzący do konsumpcji zrównoważonej i utrzymać go na stałe. Jest na każdym kroku wabiony przez działania marketingu transakcyjnego, z jednej strony, i prowokowany przez hedonistyczny styl życia rówieśników $-z$ drugiej. Dlatego ważne jest, żeby zarówno producenci, jak i nabywcy wciąż podejmowali działania, które pozwolą kreować style życia zgodne z celami zrównoważonego rozwoju, a także zwiększać świadomość społeczeństwa w tym obszarze. Jeżeli młode pokolenie nie dostosuje się do zaleceń ekologicznego, racjonalnie konsumującego i prospołecznego zachowania, to prognozy dotyczące zagrożenia o wysokim skażeniu środowiska naturalnego i wyczerpaniu zasobów mogą się urzeczywistnić, co spowoduje katastrofę o skali globalnej.

Można również zauważyć, że temat młodych konsumentów w kontekście zrównoważonego rozwoju jest bardzo mało popularny w polskiej literaturze naukowej. Jednak zainteresowani tą kwestią nie powinni być tylko badacze, lecz także praktycy biznesowi. Przeprowadzona próba typologii młodych konsumentów dostarczyła wiedzy na temat zachowania tej grupy, która nabywa dobra i usługi w sposób zrównoważony. Informacje z tego zakresu stanowią podstawę do określenia strategii marketingowej nie tylko jednostek gospodarczych, które planują skierować swoją ofertę do tego konkretnego segmentu, ale też przedsiębiorstw zamierzających szerzyć prospołeczne i proekologiczne postawy wśród konsumentów.

Należy również zwrócić uwagę, że style życia wciąż ulegają zmianom, ponieważ gusty i preferencje młodych, a także starszych osób ewoluują z czasem. Przedsiębiorcy powinni regularnie obserwować te przeobrażenia i na ich podstawie wnioskować o przyszłych wydarzeniach na rynku. 


\section{Bibliografia}

Adamczyk G. (2014), Wybrane aspekty zachowań młodych konsumentów w nowych realiach rynkowych, „Handel Wewnętrzny” 1 (354), s. 5-16.

Andruszkiewicz K. (2016), Zachowania konsumentów na rynku produktów prozdrowotnych w dobie digitalizacji rynku, „Nierówności Społeczne a Wzrost Gospodarczy” 45, s. 113-121.

Antonides G., Van Raaij W.F. (2003), Zachowania konsumenta. Podręcznik akademicki, Warszawa. Dubis M. (2014), Wartości i style życia młodzieży, „Jagiellońskie Studia Socjologiczne” 1, s. 35-45.

Duliniec E. (1986), Postępowanie nabywców towarów konsumpcyjnych w krajach o gospodarce rynkowej. Analiza marketingowa, Warszawa.

Escher I., Petrykowska J. (2015), Proekologiczne zachowania młodych polskich konsumentów, „Handel Wewnętrzny” 2 (355), s. 128-141.

Fatyga B. (1999), Dzicy z naszej ulicy. Antropologia kultury młodzieżowej, Warszawa.

Feldman S., Thielbar G. (1975), Life Styles. Diversity in American Society, Boston-Toronto.

Foxall G.R., Goldsmith R. (1998), Psychologia konsumenta dla menedżera marketingu, Warszawa. Jawłowska A. (1975), Drogi kontrkultury, Warszawa.

Kozłowski W., Rutkowska A. (2016), Konsumpcjonizm a marketing społecznie zaangażowany, [w:] Społeczna odpowiedzialność i zrównoważony rozwój w naukach o zarządzaniu, red. J. Ejdys, Toruń, s. 235-251.

Kryk B. (2011), Konsumpcja zrównoważona a proekologiczne style życia, „Studia i Materiały Polskiego Stowarzyszenia Zarządzania Wiedzą" 51, s. 207-218.

Kryk B. (2013), Zrównoważona jakość życia a zrównoważona konsumpcja i zachowania ekologiczne polskich konsumentów, „Handel Wewnętrzny” 2 (6), s. 5-18.

Mazurek-Łopacińska K. (2011), Postmodernistyczna kultura konsumpcyjna w ksztattowaniu popytu i stylów życia współczesnego konsumenta, „Konsumpcja i Rozwój” 1, s. 47-57.

Mazurek-Łopacińska K., Sobocińska M. (2009), Ekologiczna płaszczyzna społecznej odpowiedzialności przedsiębiorstw, [w:] Ekonomia. Gospodarka a środowisko, red. T. Borys, B. Fiedor, Wrocław, s. 105-106.

Mróz B. (2009), Sarmata czy obywatel świata? Polski konsument w globalnej wiosce, [w:] Konsument. Gospodarstwo domowe. Rynek. Polska - Europa, red. Z. Kędzior, M. Jaciow, Katowice, s. 13-33.

Mruk H. (2011), Zwiąki konsumpcji z rozwojem społeczno-gospodarczym, „Konsumpcja i Rozwój" 1 , s. 16-25.

Neale A. (2015), Zrównoważona konsumpcja. Źródła koncepcji i jej zastosowanie, „Prace Geograficzne" 141, s. 141-158.

Olejniczuk-Merta A. (2007), Rynki młodych konsumentów w nowych krajach Unii Europejskiej, Warszawa.

Rich M. (2008), Millennial students and technology choices for information searching, „The Electronic Journal of Business Research Methods" 6, nr 1, s. 73-76.

Rudnicki L. (2009), Styl życia jako czynnik ksztaltujacy zachowanie konsumenta na rynku turystycznym, „Zeszyty Naukowe Małopolskiej Wyższej Szkoły Ekonomicznej w Tarnowie” 3 (14), s. 11-19.

Solomon M.R. (2006), Zachowania i zwyczaje konsumentów, Gliwice.

Sowa I. (2002), Identyfikacja preferencji konsumpcyjnych wybranych grup ludności Polski, [w:] Konsument i jego wybory rynkowe, red. E. Kieżel, Katowice, s. 159-188.

Sowa I. (2016), Wykorzystanie koncepcji stylu życia w typologii młodych konsumentów, „Zeszyty Naukowe Uniwersytetu Ekonomicznego w Katowicach” 7 (303), s. 134-151.

Ekonomia — Wroclaw Economic Review 23/4 (2017)

(C) for this edition by CNS 